\title{
Book Review - Do No Harm: Stories of Life, Death and Brain Surgery
}

\section{Resenha do livro - Sem causar mal: Histórias de vida, morte e neurocirurgia}

\author{
Gilvan Aguiar da Silva ${ }^{1}$ Elton Gomes da Silva ${ }^{2(0)}$ \\ ${ }^{1}$ Universidade Federal de Integração Latino-Americana do Brasil \\ (UNILA), Foz do Iguaçu, PR, Brasil \\ 2 Sociedade Brasileira de Neurocirurgia do Brasil (SBN), Universidade Federal \\ de Integração Latino-Americana do Brasil (UNILA), Foz do Iguaçu, PR, Brasil \\ Arq Bras Neurocir 2020;39(1):33-34.
}

\begin{abstract}
Address for correspondence Gilvan Aguiar da Silva, Universidade Federal de Integração Latino-Americana do Brasil (UNILA), Foz do Iguaçu, PR, 85870901, Brasil (e-mail: gilvanaguiar@hotmail.com).
\end{abstract}

\begin{abstract}
Keywords

- neurosurgery

- medical education

- ethics

- medical errors

In the present article, we review the book Do No Harm: Stories of Life, Death and Brain Surgery, by British neurosurgeon Dr. Henry Marsh, a book that can offer a significant contribution to medical education regarding the ethics and vocation for neurosurgery.

\section{Resumo \\ Palavras-chave \\ - neurocirurgia \\ - educação médica \\ - ética \\ - erros médicos}

Neste artigo, elaboramos uma resenha do livro Sem causar mal: histórias de vida, morte e neurocirurgia, escrito pelo neurocirurgião inglês Dr. Henry Marsh, uma obra que pode ser de contribuição significativa para a educação médica no que se refere à ética e à vocação para a neurocirurgia.
\end{abstract}

\section{Introduction}

Doctors are fallible, and although they try to stay protected under an armor of superiority and detachment, they can also feel anxiety and fear before surgery. In the book Do No Harm: Stories of Life, Death and Brain Surgery, ${ }^{1}$ Dr. Henry Marsh, a renowned British neurosurgeon, with a particularly realistic approach and devoid of any passionate vision for the profession, bares the myths that patients have regarding physicians, revealing the human and also fallible face of the profession, in addition to the ethical dilemmas and the emotional exhaustion that these professionals suffer in the course of their careers.

This incredible saga of exciting stories of neurosurgery that Dr. Marsh faced during his career enables a deep immersion in what the life of a neurosurgeon is, and it is told with some excerpts of explanatory technical reports of how the surgeries or the issues that will be operated on arise, and there are also moving life histories of the patients on whom he operated throughout his career.

Unlike some biographies or non-fiction books that show a mythical view of the neurosurgeon as the typical student who has always been the best in school, and is intelligent and almost an enlightened being, right in the book's initial pages, Dr. Marsh tells the reader how the beginning of his career happened, and humbly emphasizes that he was no superstudent during high school. On the contrary, practically not having received scientific education, he was rejected by most medical schools in England, and ended up being accepted to a school of medicine with a class of students with poor results in high school (p. 82). He also tells his experiences in his previous work as a nurse in a received

November 10, 2017

accepted

January 5, 2018
DOI https://doi.org/

10.1055/s-0038-1639498. ISSN 0103-5355.
Copyright $(2020$ by Thieme Revinter

Publicações Ltda, Rio de Janeiro, Brazil
License terms

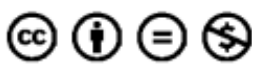


home for the elderly, where he performed the most diverse tasks, which most people would consider unpleasant (p. 84), and how all of this was important for his career: "I am less afraid of failure; I was able to accept its existence and feel less threatened by it" (p. 92).

In this sense, facing moral and ethical dilemmas of ineffable complexity in his daily life, the author demonstrates his point of view that it is not difficult to know when to operate: the difficulty lies in deciding when not to operate, because, in some cases, surgeries have very high chances of failure, and the operated patient can have a very short, extremely dependent, painful, dramatic and hurtful survival, which makes the concept of success relative. Thus, he declares that: "The problem is when there is no certainty between operating or not. It is easy to be wise in retrospect" (p. 242-243), or, in a controversial way, he says: "In some cases, it is better to let someone die than to operate" (p. 131).

This form of reasoning can leave the false impression that the author is devoid of any ethics or feelings toward his patients, but the reader soon realizes that this is a terrible mistake, especially when he exemplifies his reasoning, describing how he eventually decided to operate on some patients who he knew to be terminally ill due to cowardice to confront the family and tell them the truth (p. 145), and how unpleasant these experiences were for all of those involved. He also describes a personal case that was quite moving, when his own mother was diagnosed with an incurable cancer and was sent home to die, a much less painful experience than it could have been in a hospital environment (p. 203).

Over the course of the stories, it is easy to see that although Dr. Marsh has become an extremely pragmatic and rational professional throughout his career, who does not believe in miracles, it is precisely this characteristic that enables him to develop a touching and profound involvement with his patients, for example, when he emphasizes his view that he does not feel rewarded by a grateful patient who returns several times to the office with gifts or compliments, but only feels really rewarded when his patients forget about him, for this means that they were healed (p. 42). It would be easy to write a book only with the cases of success and happiness, but it takes a lot of self-confidence and courage to take on the failures that are inevitable throughout anyone's life. Thus, by promoting this shock of reality and showing that physicians are also human and make mistakes, Dr. Marsh makes us reflect about the pressure to which these professionals are subjected, for they need to make quick decisions and are surrounded by the constant risk of making mistakes, because when neurosurgery errors occur, the results are usually catastrophic (p. 163).

One of these cases is that of a young athlete who ended up having the root of a nerve severed due to an error by one of his residents (but in which case he was also partially guilty) that made the patient unable to lift his foot, and he became limp and unable to run or ride a bike (p. 161, 180 and 183). There are still cases of patients who suffered strokes during operations and became incapable of speaking and understanding what is said, becoming almost disconnected from the real world (p. 192), or even the regret he feels for having let himself be convinced in the past to perform a psychosurgery (p. 125).
Other cases of errors or more dramatic complications are narrated, and in them the author exposes how the term "complications" is sometimes used as a euphemism for real chaotic scenes of uncontrolled hemorrhages or situations bordering on despair (p. 108 and 244).

In several passages, the author describes the burdens that come with the profession: he states that he behaved in an exultant manner before surgery at the beginning of his career, but also describes how difficult it is to maintain optimism and enthusiasm after many years into the profession, after having witnessed stories of despair, surgical complications, and weak results (p. 11). Therefore, it is expected that neurosurgeons feel anxiety and fear before operating (p. 47); the thing is that they cannot show this to the team or the patients: it is a weight that they need to carry alone.

In fact, some neurosurgeons, at the end of their careers, can suffer from psychological problems, such as anxiety or depression, due to the great stress to which they are subjected, with a routine of little time for the family and a lot of time surrounded by tragic stories. This becomes very clear, for example, on the day that Dr. Marsh had to interrupt a stroll in his rare time off to give a patient the terrible news that he would inevitably die, thus being shaken throughout the remainder of the day ( $p$. 158 ), or even as all this routine of lack of time and stress led to the end of his first marriage (p. 21).

Many young medical students feel seduced by the specialty of neurosurgery, which is even perceived by some as the position of highest medical status, but few can imagine how dramatic and sufferable a lifetime devoted to neurosurgery can be when dealing with reality itself: "A typical career in neurosurgery involves death, discussions and sequelae" (p. 137), so it is not enough to have a calling for the profession, it is also necessary to have a realistic view of the environment in which you will have to live: "Neurosurgery is a horrible work, full of sorrows and disappointments, do not follow this path" (p. 194), advises the author.

Therefore, we conclude that this work, besides enabling the reader to have a notion of how some neurosurgeries are performed, provides incredible lessons and exciting stories, culminating in a profound analysis about medical ethics. Therefore, from the point of view of medical education and calling for neurosurgery, this work may be a reality check to subsidize the decision of students who still have doubts about the career they want to follow. In fact, the format adopted by the author, unlike the traditional academic writings of the field of science, makes the text extremely accessible, light and pleasant, a compelling read, and that also makes this work an instrument of scientific disclosure that can be used even as a complementary read in postgraduate or scientific initiation courses in the field of health sciences.

\section{Conflict of Interests}

The authors have no conflict of interests to declare.

\section{Reference}

1 Marsh H. Do No Harm: Stories of Life, Death and Brain Surgery. São Paulo, SP: Editora Nversos; 2017 